Illinois State University

ISU ReD: Research and eData

Theses and Dissertations

3-18-2016

\title{
Macro And Micro Levels Of University Identification: Using Social Network Sites To Reactivate Latent Social Identities Within College Alumni
}

Eric James Varney

Illinois State University, ejvarne@gmail.com

Follow this and additional works at: https://ir.library.illinoisstate.edu/etd

Part of the Communication Commons

\section{Recommended Citation}

Varney, Eric James, "Macro And Micro Levels Of University Identification: Using Social Network Sites To Reactivate Latent Social Identities Within College Alumni" (2016). Theses and Dissertations. 551.

https://ir.library.illinoisstate.edu/etd/551

This Thesis is brought to you for free and open access by ISU ReD: Research and eData. It has been accepted for inclusion in Theses and Dissertations by an authorized administrator of ISU ReD: Research and eData. For more information, please contact ISUReD@ilstu.edu. 


\title{
MACRO AND MICRO LEVELS OF UNIVERSITY IDENTIFICATION: USING SOCIAL NETWORK SITES TO REACTIVATE LATENT SOCIAL IDENTITIES WITHIN COLLEGE ALUMNI
}

\author{
Eric J. Varney
}

\section{Pages}

This master's thesis sought to extend social identification research further into social network sites by examining how online interactions may affect offline behaviors. In particular, this thesis argues that alumni who interact with their university or major department via a social network site, should have an increased intention to donate back to their university or major. Despite a large body of research on both social identification and social network use, less research has combined the two in order to predict external behaviors. As such, data were collected from 277 undergraduate and graduate students at Illinois State University regarding their university and major social identification as well as their social network use. Data were analyzed using a $t$-test and multiple linear regressions. The findings from this research suggest that social network site use is a significant variable to increase an alumni's intent to donate. However, contrary to previous research, superordinate university social identification was a stronger predictor of intent to donate when compared to subordinate major social identification. The 
findings support the prediction that social network interaction plays a significant role in predicting an alumni's intent to donate to their university.

KEYWORDS: Alumni, Donation, Social Identification, Social Identity Theory, Social Network Sites. 


\title{
MACRO AND MICRO LEVELS OF UNIVERSITY IDENTIFICATION: USING SOCIAL NETWORK SITES TO REACTIVATE LATENT SOCIAL IDENTITIES WITHIN COLLEGE ALUMNI
}

\author{
ERIC J. VARNEY
}

\begin{abstract}
A Thesis Submitted in Partial Fulfillment of the Requirements for the Degree of MASTER OF SCIENCE

School of Communication

ILLINOIS STATE UNIVERSITY
\end{abstract}


(C) 2016 Eric J. Varney 
MACRO AND MICRO LEVELS OF UNIVERSITY IDENTIFICATION: USING SOCIAL NETWORK SITES TO REACTIVATE LATENT SOCIAL IDENTITIES WITHIN COLLEGE ALUMNI

ERIC J. VARNEY

COMMITTEE MEMBERS:

Caleb T. Carr, Co-Chair

Stephen Hunt, Co-Chair

Cheri Simonds 


\section{ACKNOWLEDGMENTS}

First, I would like to express my sincere gratitude to my thesis advisor, Dr. Caleb Carr, for his continuous support, patience and motivation. His guidance was instrumental in the completion of this thesis. Whenever I hit a roadblock or began to doubt myself, he would pull me back to reality and put me back on the right path. Even when we suffered extreme setbacks, he was able to provide me invaluable advice on how to make the most of our situation. I truly could not have completed this thesis without him.

Besides my advisor, I would like to thank the rest of my thesis committee: Dr. Steve Hunt and Dr. Cheri Simonds, for their insightful comments, encouragement and ability to ask the hard question that helped me expand my research. Their feedback helped strengthen my overall argument and made my research more accessible to a broader audience who may not have as much experience with computer mediated communication theory.

Last but not the least, I would like to thank my family: my parents, Jeff and Brenda, and my sister, Katie, for supporting me throughout this thesis and my life in general. As they know, this has been a long process and their constant support has made this journey worthwhile.

E. J. V. 


\section{CONTENTS}

Page

ACKNOWLEDGMENTS $\quad$ i

CONTENTS

CHAPTER

I. THE PROBLEM AND ITS BACKGROUND 1

Statement of the Problem 1

II. REVIEW OF RELATED LITERATURE 4

$\begin{array}{ll}\text { General Literature Review } & 4\end{array}$

Engaging Alumni 4

Social Identity $\quad 6$

Organizational Identification $\quad 10$

Workgroup Identification 13

University Organizational Identification $\quad 14$

Major Workgroup Identification 16

Waning University and Major Social Identification $\quad 17$

$\begin{array}{ll}\text { Social Network Sites } & 17\end{array}$

III. RESEARCH DESIGN 24

$\begin{array}{ll}\text { Method } & 24\end{array}$

Procedures $\quad 24$

Respondents 25

Measures $\quad 25$

IV. ANALYSIS OF THE DATA 29

$\begin{array}{lr}\text { Statistical Analysis } & 29\end{array}$ 
V. SUMMARY, CONCLUSIONS, AND RECOMMENDATIONS

Summary of the Research and Findings 32

General Discussion $\quad 32$

Implications for Theory 33

Implications for Practice $\quad 35$

Limitations and Future Research $\quad 37$

Conclusion $\quad 41$

REFERENCES $\quad 42$

APPENDIX A: Informed Consent $\quad 50$

APPENDIX B: Survey Instrument 52 


\section{CHAPTER I}

\section{THE PROBLEM AND ITS BACKGROUND}

\section{Statement of the Problem}

Individuals have multiple group memberships that influence various behaviors. Each membership fosters a unique social identity that defines an individual's sense of self. Separate social identities are concurrently held, but each identity is activated individually depending on the social context. When a social identity is activated, the individual's attitudes and behaviors are guided based on the norms of that group and its members. This leads individuals to act in ways that conform to their social identity. However, when individuals are distanced, either socially or geographically, from a group; the group's social identity becomes less salient. Social network sites (SNSs) can play a critical role in the (re)activation of social identities because they allow users to maintain and activate latent and weak ties over large geographic distances (Ellison, Lampe, \& Steinfield, 2007). If used properly, social network sites could be used to reactivate latent identities by allowing individuals to reconnect with their previous social identification group(s). This reactivates a particular social identity, making it salient once more. One place where this may be of particular interest is with college alumni.

When students graduate college, they leave with a social identity that has been shaped throughout their college career (Gaier, 2005). As graduates distance themselves physically and mentally from their university, their university social identification 
becomes less salient and thus, their attitudes and behaviors are guided less by their college identification. If universities can reactivate latent social identification, then alumni may subsequently shift their behavior and attitudes to act more favorably towards an institution, leading them to increasingly consider volunteerism, guest lecturing, or even providing monetary donations.

Since the late 1970s, there has been a 30 percent decrease in the amount of state appropriated funds for higher education institutions (Archibald \& Feldman, 2006). This decline in state funds has led many institutions to become increasingly reliant on supplementary funding. In 2010, educational institutions nationwide received an estimated 4.6 billion dollars in charitable donations (Giving USA, 2010). However, McDearmon (2013) states, "although the amounts contributed to colleges and universities in the U.S. have seen steady increases over the years, the actual number of alumni who have contributed continues to fall" (p. 284). This presents the serious issue that the number of alumni donating is steadily decreasing. It has been noted that university social identification may not be the only vital element for alumni donation. Many researchers have argued that identifying with a specific major or major related extracurriculars could be a better predictor of alumni donations (Clotfelter, 2002; Monks, 2003; Okunade \& Berl, 1997)

By using social media to activate latent social identification with a university or major, it may be possible to activate specific behaviors, such as volunteerism, guest lectures, and donation. This research seeks to understand the relationship between the use of social network sites and the reactivation of weak or latent identities, and by extension 
the impact on various university-related behaviors of alumni. 


\section{CHAPTER II}

\section{REVIEW OF RELATED LITERATURE \\ General Literature Review}

\section{Engaging Alumni}

The study of alumni donation habits has been prominent over the past 30 years. Researchers suggest there are numerous factors that predict alumni engagement behavior. Some studies have found that personal characteristics such as age, income, and gender contribute to alumni engagement behaviors (Tsao \& Coll, 2005; Weerts \& Ronca 2007), while others state that participation in extracurricular activities such as Greek life, athletics, and clubs are strong predictors as well (Stevenson and Yerger, 2014).

However, across reviewed literature, a wealth of research found that creating a positive alumni experience by building relationships and interacting with alumni will increase university engagement (Lertputtarak \& Supirchayangkool, 2013; Coltfelter, 2001). Sun et al. (2007) found that having a positive alumni experience significantly increases the likelihood of donations as compared to alumni with a negative alumni experience. Other research has concluded that alumni organizations who implement a customer relationship strategy were better able to maintain and improve the relationship between the alumni and their university, leading to more alumni engagement (Ahmadi et. al, 2012). This emphasis on relationships and interaction has caused both the creation and reinvention of alumni associations and their respective outreach programs. 
Traditionally, universities seek alumni engagement in the form of time (volunteerism), talent (guest lectures/networking) and treasure (money). While many alumni consider participating in engagement behaviors, their relative distance from the university can make it challenging for them to participate in on campus engagement, making donation their primary form of alumni engagement.

Due to their respective age and income, older alumni donate more money than younger alumni (Stephenson, 2013; Clotfelter, 2001), making them prime targets for engagement opportunities. Alumni outreach programs traditionally communicate through the use of informational mailers, phone calls, newsletters, dedicated alumni webpages and email list servs. With so many options available, the frequency and quantity of communication can be overwhelming for some alumni, who may eventually view university communication as an annoyance rather than being informative (Kowalik, 2011). As the generational gap continues to grow, millennials are not responding to these traditional forms of alumni outreach (Kowalik, 2011), driving many universities to create and maintain social network accounts in an attempt to engage these younger alumni. While social network sites are an effective tool for young alumni, some older alumni may lack the comfort to navigate social networks, so traditional methods are still widely used (Zeng, Hall, \& Pitts, 2012).

Social network sites allows for a level of interactivity not matched by traditional means of alumni outreach. While informational mailers can reach a large number of alumni, they lack a convenient and meaningful way to respond. Social network sites have the ability to reach thousands of alumni with one post in a very inexpensive manner 
(Zeng, Hall, \& Pitts, 2012). Additionally, the sharing features on social network sites allows for an even larger visibility to alumni who may not follow the university's account. By constantly interacting via social network sites, universities can maintain their relationship with their alumni and reactivate their affinity towards the university. Ford and Merchant (2010) found that reactivating nostalgic memories related to significant experiences are beneficial when attempting to solicit alumni engagement. Researchers have built on the use of nostalgia by introducing attitude accessibility, how quickly an attitude is activated, into their engagement research.

\section{Social Identity}

Social identity is conceptualized as an individual's "membership of a social group together with the value and emotional significance attached to that membership" (Tajfel, 1978, p. 67). By associating with a certain groups, individuals can increase their selfesteem by identifying with others who share common values and interests, which helps build their self-esteem. Tajfel \& Turner (1979) built upon this concept, theorizing individuals do not have singular selves, and instead are collections of selves that correspond with different group affiliations. This idea became the foundation of Tajfel and Turner's (1979) social identity theory (SIT). At its core, SIT is used to understand how intergroup phenomena guide an individual's self-concept (Amiot \& Aubin, 2013). In order to have a social identification, it is necessary to have a social group consisting of more than two people sharing the same social identity (Hogg \& Reid, 2006). As individuals perceive a relationship between their self-concept and their group membership(s), they begin to develop common values and interests with individuals in 
that group (Hogg \& Reid, 2006). Thus, SIT is used to account for how people strive to maintain or enhance their self-esteem, and therefore identify with social groups that are esteem boosting (Tajfel \& Turner, 1986). However, developing a social identity is not as simple as associating with various groups. Tajfel and Turner (1979) offer two specific concepts that lead to the creation of social identities: categorization and selfenhancement. These elements fulfill an individual's esteems needs and satisfy ingroup favoring.

Categorization. Categorization occurs when individuals compare themselves with others and assess their relative similarity or dissimilarity (Stapel \& Koomen, 2000). More simply, it is the process of deciding to which group(s) an individual belongs. Categorization helps individuals reduce uncertainty about group membership by understanding the social contexts and behavioral norms present within a particular group. This understanding of group norms allows individuals to make more accurate assessments of groups and thus, reduces their uncertainty. In this way, individuals can evaluate a group and its members by placing values on the attractiveness of group membership (Stets \& Burke, 2000). When people are categorized into groups, they are perceived in relation to the characteristics of that specific group. For example, if someone is categorized as a nerd, there are specific identification markers that society associates with being in the nerd social group (i.e., spending an excessive amount of time studying, awkward social interactions, or playing video games all weekend) and certain behaviors and attitudes a nerd is expected to exhibit. Categorization helps individuals locate themselves and others within their social environment (Mael \& Ashforth, 1992), and 
establish ingroup/outgroup bias. The ingroup/outgroup bias occurs when individuals favor members of their own social group and disaffiliate with members of other social groups based on their own groups attractiveness (Brewer, 1979).

Turner (1987) argues there are two critical factors that predict categorization: fit and accessibility. Fit and accessibility have been factors of categorization since Bruner's (1957) initial conception of the accessibility and fit formula. Bruner's formula predicts how individuals categorize themselves into salient social identities based on their perceived levels of fit and accessibility.

Fit. According to Reicher, Spears, and Haslam (2010), fit has two subcategories, comparative fit and normative fit. Comparative fit, "refers to the social organization of similarities and differences between people in a given context" (Reicher, Spears, Haslam, 2010, p. 20). This means that individuals will compare their personal beliefs and values to those of current group members in order to assess whether they could be a member of that group. Normative fit is used to reflect upon a group's shared features and how you would expect them to act based on those features. For example, in high school there are various social groups that one could belong to (i.e. athletics, theatre, band, goth). Each of these groups have their own set of norms and behaviors that one would expect to see while interacting with them. The athletic students may wear letterman jackets and talk about sports and the goth students may dress in black and be socially distant. These levels of normative fit, "arise from the (expected) content associated with similarities and differences between people" (Reicher, Spears, Haslam, 2010, p. 21). 
Accessibility. After assessing fit, individuals will select a social group based on their perceived positive or negative fit. From there, individuals begin to assess the accessibility of a social group. Accessibility is the perception of how easily an individual could actually gain entrance into a social group. This perception of accessibility is usually determined by the perceivers' past experiences with similar social groups (Blanz, 1999). If individuals feel the social group's barrier to entry is too high, they will reassess their fit and potentially find another social group.

Once fit and accessibility are satisfied, individuals will begin to base their selfconcept on their group affiliation, causing them to internalize the norms and values of their social group. This is the beginning of the ingroup/outgroups phenomena known as self-enhancement.

Self-Enhancement. Self-enhancement causes individuals' self-concepts to become intertwined with the values of their social identification groups. Individuals tend to identify with groups they perceive as distinct and attractive, because these memberships enhance their own self-esteem (Sluss \& Ashforth, 2008) due to their perception of the ingroup as superior to the outgroup. As individuals begin to perceive their social group as the ingroup, they begin to distance themselves from other groups, firmly establishing the ingroup/outgroup bias.

When individuals identify with a social group, they tend to act in ways that correspond with their salient social identity (Edwards, 2005), resulting in numerous positive behaviors towards their social group. Self-enhancement also fulfills individuals' esteem needs. By comparing their ingroup to a perceived outgroup, individuals view their 
group and themselves, in a more positive light; leading to increased group affinity and social identification.

A social identity provides an individual with a sense of self-esteem and a framework for how to act in certain social situations. When a social identity is active, it guides the behaviors and attitudes of individuals, leading them to act in ways that conform to group norms (Hogg \& Reid, 2006). However, it is naive to believe individuals have only one social identity to manage, because with different group affiliations comes the development of multiple social identities. For example, a college student has many different social identities (i.e. son, brother, husband, Chicago Blackhawks fan, gamer, student, Teenage Mutant Ninja Turtle fan, etc.). These social identities become harder to manage as they increase in number, in part because they come to link the individual with increasingly disparate groups.

Individuals' social identities are concurrently held, but individually activated. This means that in order for a social identity to become salient, something must first trigger its activation. Once identities become salient they "increase the influence of one's membership in that group on perception and behavior" (Oakes 1987, p. 118). This identity activation is evident when examining organizations and workgroups.

\section{Organizational Identification}

SIT (Tajfel \& Turner, 1979) has been used to frame organizations as social identification groups by illustrating the multiple social identities relevant to organizational members (Scott, 2007). Organizational identification (OI) is defined as, "a perceived oneness with an organization and the experience of the organization's 
successes and failures as one's own” (Mael \& Ashforth, 1992, p. 109). Simply put, organizational identification refers to how individuals perceive themselves as a member of an organization (Ashforth, Harrison, \& Corley, 2008).

Like social identification, organizational identification is used to help individuals categorize themselves into an organization's structure by allowing them relate to a collective and create an ingroup favoring within an organization (Dutton et al., 1994). Organizational identification emphasizes individuals locating themselves within the confines of their organizational roles and affiliations, allowing them to understand the extent to which they identify with the organization as a whole. As individuals began to internalize the beliefs and actions of their organization, those beliefs become selfdefining and contribute to the development of an individual's organizational identification (Pratt, 1998). Pratt (2001) found that organizational members who more strongly identify with their organization are more likely to engage in and make decisions that favor the organization, further resulting in a variety of positive outcomes such as increased job satisfaction and better job performance (Albert, Ashforth, \& Dutton, 2000). Decoster et al. (2013) also found employees who identify with the organization are likely to support (i.e. trust and understand) their company in good and bad times.

The perception of the organization itself can play a crucial role in the development of strong organizational identification. Ashforth, Mael, and Dutton (1994) identify three aspects of an organization that could strengthen a member's organizational identification; 1) the organization is perceived to be highly prestigious, 2) the organization has an attractive image, and 3) identifying with the organization increases a 
member's self-esteem. If one or more of these aspects are present, they could enhance an individual's social identification.

Organizational Prestige. Individuals identify with organizations for various reasons, but their association with an organization is partially driven by esteem needs. If an organization is perceived as being highly prestigious (i.e. the organization is well regarded by both employees and non-employees), there is a greater chance for an esteem boost through identification (Mael \& Ashforth, 1992), which increases the likelihood of strong organizational identification (Fisher \& Wakefield, 1998). However, organizational prestige is based on an individual's perception of the organization, not the actual prestige of an organization.

Attractive Image. Members of an organization often attempt to project an image of social desirability by conveying an attractive image (i.e., being a fun place to work, having good benefits, and having a good reputation). Organizational members have the ability to showcase an organization's image by rewarding employees and participating in charitable events to emphasize the positive image of the organization (Gioia, Schultz, \& Corley, 2000). If an organizational member perceives their organization to be attractive, then they have an increased likelihood of having stronger organization identification.

Esteem Needs. Organizational prestige and attractive image are not the only factors in an organizational member's perceived fulfillment of esteem needs. When members' organizational identification is strong, they may begin to incorporate what the organization believes is distinct, central, and enduring into their own self-concept (Dutton, Dukerich, \& Harquail, 1994). If these beliefs become a part of an individual, 
then they should perceive their organizational identification as fulfilling their esteem needs.

Thus, the development of organizational identification is not solely an interactive process because the organization can directly affect a member's level of identification. However, concepts of identification development do not solely apply to the organization at a macro-level. There are multiple subgroups that make up the micro-level of an organization's structure with which an individual may identify; the most notable being workgroups. These workgroups have an identification process that is similar to organizational identification, but are distinct in their own right.

\section{Workgroup Identification}

Workgroup identification (WI) is the extent to which individuals define themselves in terms of a smaller, more intimate social group within the workplace (Cooper \& Thatcher, 2010). Individuals in workgroups share more common interests than those who identify with the organization at a macro-level (van Knippenberg \& van Schie, 2000). While in an organization, individuals spend the majority of their time in workgroups, and thus develop high levels of familiarity and cohesion among other workgroup members (Riketta \& Van Dick, 2004). This cohesion leads to more information disclosure between workgroup members (van Knippenberg \& van Schie, 2000). Additionally, workgroups usually have more direct and immediate influence over its members than the organization does (Riketta \& Van Dick, 2004).

Vough (2011) found that workgroup identification is more strongly associated with job satisfaction, reduced turnover intentions, job involvement, and job motivation 
than organizational identification. WI also "predicts ingroup[/outgroup] bias if the ingroup and outgroups are viewed as relatively distinct, task independent, and goal independent and if the ingroup culture does not discourage such bias" (Ashforth, Harrison, \& Corley, 2008, p.337). As a result, workgroup identification is better able to predict the attitudes and behaviors of the workgroup members.

In most organizational contexts, employees are likely to interact with members of their workgroup more frequently than members of other organizational groups. Thus, their workgroup identification should be more salient than their organizational identification (Riketta \& Dick, 2004). Additionally, workgroups are a more proximate entity than the organization itself, leading employees to perceive a sense of control. The result is a stronger identification with their workgroup rather than to the organization as a whole (Mueller \& Lawler, 1999).

\section{University Organizational Identification}

A prime example of the organization/workgroup dichotomy exists in the realm of education. By examining a university at the macro-level, one can compare it to an organization because the university has multiple large-scale goals that are executed by various individuals and groups within the university's structure. Additionally, these individuals and groups begin to develop an affinity towards the university, very similar to how employees would identify with an organization. Gaier (2005) discusses how the quality of the relationship between one's alma mater and an alumnus postgraduate plays a large role in the creation of organizational identification. The establishment of OI is mutually beneficial for both the institution and alumni for a number of reasons. By 
borrowing organizational identification elements from Ashforth, Harrison, \& Corley (2008) (organizational distinction, the organization's outgroups are salient, and intergroup competition exists between ingroups and outgroups), universities can begin to determine the degree to which a student or alumni will internalize the characteristics or perspectives of the university.

In terms of an organization being distinct from others, it is in a university's best interest to find ways to stand out amongst other universities. One way they can do this is by providing opportunities for their students to become entrenched within university ingroups. These include extracurricular activities, a fun social and academic atmosphere, athletics, intramurals, and clubs. The academic and social components of college work in tandem to shape a student's experience. Gaier (2005) found that student participation in on-campus groups and activities was a significant factor in both alumni giving and alumni participation. Gaier (2005) reports that, "alumni who participated in at least one formal student activity during the undergraduate experience were $87 \%$ more likely to give and 1.5 times as likely to participate as those alumni who did not participate in any student activities as undergraduates” (p. 284).

Secondly, a university must offer a salient outgroup. Outgroups are readily presented and salient in a university context due to athletic and academic rivalries. Outgroups, and their members, are considered significantly less similar when compared to the ingroup, thus creating a bias against the outgroup. This causes negative categorizations, feelings, or ideas about the people who are part of the outgroup (JacobySenghor, Sinclair, \& Smith, 2015). For example, one of the biggest rivalries in college 
football is Oregon State vs. University of Oregon. If a group of Oregon State fans sees someone dressed in green and yellow (University of Oregon's colors) they would feel a negative bias towards that person due to their own association as an Oregon State ingroup member. This interaction will also begin to deindividuate the Oregon State fans, meaning they will no longer see themselves as individual people, rather as a collective group of Oregon State fans united in their University of Oregon outgroup bias. While having a salient outgroup is not the only antecedent of deindividuation, it helps create a greater affinity for the ingroup to which an individual then conforms. In other words, individuals begin to lose their sense of individual identity and become entrenched in the group norms.

\section{Major Workgroup Identification}

Beyond and subordinate to a university social identification as organization identification, the various college majors (i.e., Communication, Psychology, Sociology) can be considered as workgroup identification sources. The different majors are equitable to workgroup identification due to the more intimate nature of identification, created by specialized interests, as compared to university level identification. This intimacy creates opportunities for greater social identification. Kim, Chang, and Ko (2010) found that undergraduate students who identify with their academic department [major] have a stronger identification as compared to their university identification. They also found that individuals who had strong major identification were more likely to have supportive intentions. 


\section{Waning University and Major Social Identification}

Once individuals graduate, they begin to distance themselves, both physically and socially, from their universities, causing their university and major identification to become less salient among their other social identities as they are replaced by new organization identities, like jobs. This identity latency reduces alumnus' likelihood to behave positively towards a university because they no longer identify as heavily with the social identity norms and beliefs of the university. As alumni spread across the country, how can a university reactivate university and major identifications despite this geographic hurdle to increase normative social identity behaviors, like donations? The answer may lie within social network sites.

\section{Social Network Sites}

boyd and Ellison (2007) define social network sites as, "web-based services that allow individuals to (1) construct a public or semi-public profile within a bounded system, (2) articulate a list of other users with whom they share a connection, and (3) view and traverse their list of connections and those made by others within the system" (p. 211). Social network sites are prime examples of how social identity theory can operate in an online context, as social network sites allow users to create, maintain, and express social identities with various groups despite geographic distances or time constraints.

One of the clearest applications of social identity theory within social network sites has been analyzing how social identities are maintained through online interactions (Scott, 2007). Ellison, Steinfield, and Lampe (2007) explain that social network sites are 
used to connect individuals with preexisting relationships, rather than fostering new ones. This makes SNS a valuable tool in identification because they allow for the effective maintenance of both strong and weak ties in one location. Zhao, Grasmuck, and Martin (2008) explain that individuals can also activate their different social identities by uploading photographs, updating profile information, and posting wall content. For example, if someone were to update their profile with Chicago Cubs pictures it would be safe to assume that part of their social identity is being a Cubs fan.

According to Reicher, Spears, \& Postmes' (1995) social identity model of deindividuation effects (or SIDE model), when individuals become immersed in a group they begin to develop a sense anonymity and a diffusion of responsibility. By being less individualistic and engaging in more group activities, individuals can actually increase the salience of the group's identity and thereby deindividuating them. Through SIDE, "online interactions can maximize the difference between ingroup and outgroup members, thus raising the esteem of the ingroup" (Wang, Walther, \& Hancock 2009, p. 61). SIDE suggests that the deindividuation from computer mediated communication propels users to identify with a group identity that is salient to them, whether it is an ad hoc activity group or wider social categories (Wang, Walther, \& Hancock, 2009), members no longer view themselves as individuals, but as a part of the larger group as a whole. Once the group identity is salient, the personal identity becomes less important and even interchangeable with other ingroup identification (Wang, Walther, \& Hancock, 2009). Referring back to the Oregon State vs. University of Oregon example used earlier, when the group of Oregon State fans saw a University of Oregon fan, they deindividuated 
into a collective group. However, when using social network sites, the Oregon State fans could seek out others who share their outgroup bias against University of Oregon fans and deindividuate even more with likeminded Oregon State fans.

When considering the role that SNSs play in activating university and major social identities, one must first consider the mindset of a college graduate. Typically, college students are immersed in their collegiate career for four years, after which they graduate and transition into a career. While the newly graduated alumni are away from their alma mater, their identification begins to suffer as post-graduate life moves forward. This leads alumni to disassociate with their alma mater, making their identity latent. Using social network sites to communicate with alumni allows for a new avenue of maintaining university and major social identities.

A study conducted by Farrow and Yuan (2011) is one of the most relevant examples of how social network site use influences behavioral outcomes. Their study sought to identify the effects of alumni social network use on their attitudes towards volunteering and charitable giving. Farrow and Yuan found active members of alumni Facebook groups had a higher perceived level of emotional closeness with their university than those who were not active. This demonstrates an important relationship between social network interactions with a university and an increased emotional response from the user. Since the self-enhancement aspect of social identity theory is based around esteem needs, a parallel can be drawn between emotional closeness and the self-enhancement needed to develop social identification. While it is not a direct connection, it can be hypothesize that social network use could increase university social 
identification within alumni. However, this study in not solely concerned with how alumni interact with their university via social network sites. A second area of interest includes whether the same social network interaction could activate an alumni's major social identification. Thus,

H1a: Alumni use of SNSs to communicate with their alma mater activates social identification with their alma mater.

H1b: Alumni use of SNSs to communicate with their alma mater activates social identification with their major.

However, according to Ashforth (2001) the social identities of small units (i.e. workgroups) are richer than those of large units (i.e. the organization as a whole). This should hold true in terms of university and major identification as well. DeMarie and Aloise-Young (2003) found when students take courses related to their major, they have a greater personal investment in those courses as compared to required general education courses. This leads students to give more attention and effort in their major classes, requiring general courses to capture their interest rather than assuming that students are self-motivated to learn (DeMarie \& Aloise-Young, 2003). Thus,

H2: Individuals identify more strongly with their major than with the university itself.

University and major identification cause individuals to act congruent to group norms and can activate certain behaviors. These behaviors can manifest into different actions such as donations or gifts to the university or major. Newman and Petrosko (2011) found that student involvement in major based activities as an undergraduate were predictors of alumni giving. Thus, alumni who are satisfied with their academic 
experience are more likely to be involved with the university than those alumni who are not as satisfied with their academic experience (Gaier, 2005). University and major identification traditionally require some level of both time and proximity to the institution, but it can be challenging for alumni to stay involved on campus due to their geographic location. As such, many alumni prefer a monetary donation rather than oncampus participation, because a donation can be sent via mail; whereas, participating in an event requires more energy and effort (Gaier, 2005). Referring back to Farrow and Yuan's (2011) study, alumni with a strong emotional closeness to their university have stronger positive attitudes towards charitable giving to their university. So, by extending this to social identification, one could assume that alumni who have strong levels of university social identification may also have favorable donation intentions to their university. Additionally, Ashfoth (2001) shows that individuals identify stronger with smaller workgroups compared to the larger organization as a whole, so it can also be hypothesized that major social identification should influence intent to donate as well. Thus, H3a: University social identification predicts intent to donate. H3b: Major social identification predicts intent to donate.

There has been limited research comparing how the strength of university and major social identification affects intent to donate. However, Mael and Ashforth (1992) explain that subordinate levels of social identification (i.e. workgroups) were stronger predictors of donation behaviors than superordinate levels of social identification (i.e. organization). This is further echoed by the results of a study conducted by Kim, Chang, 
and Ko (2010) that indicated when students' identified with their major, there were strong effects on their intent to support the university, explaining, "identification with [workgroups] may be as important as identification with the organization as a whole in intentions to support organizations" (Kim, Chang, \& Ko, 2010, p.424).

Strong subordinate identification may be attributed to the categorization and selfenhancement processes presented in social identity theory. Alumni categorize themselves within superordinate (i.e. university) and subordinate (i.e. major) identifications while they attend college. Using self-enhancement, alumni assess the norms and values presented in both the university and their major, ultimately identifying stronger with one over the other. Whether the stronger identification is with the university or major is still debated among researchers. Farrow and Yuan (2011) found that students who had a high level of perceived emotional closeness with the university had a stronger positive attitude towards charitable donations than those who felt less close. While Weerts and Ronca (2009) found that the major field of study is a significant determinant of alumni giving as compared to university itself. Even though the results of Weerts and Ronca showed support for major social identification's impact on intent to donate, they did not look at activating university and major social identification via social network sites.

By extending the principals of organization and workgroup identification to university and major identification, one can assume that the subordinate (workgroup/major) identification may be a better predictor of donation behaviors as compared to superordinate (organization/university) identification. Thus: 
H4: Major social identification is a stronger predictor of intent to donate than university social identity. 


\section{CHAPTER III \\ RESEARCH DESIGN}

\section{Method}

\section{Procedures}

A survey was used to test the hypotheses. Respondents were graduate and undergraduate students from Illinois State University. Due to the large population of the university, an online survey instrument was created to reach the greatest number of respondents. The survey was posted on the School of Communication Research Pool page and instructors also mentioned the survey in their classes; some offering extra credit for participation. Respondents provided informed consent before completing the survey. After consenting to participate, respondents were required to answer three preliminary questions before beginning the survey: "What academic department do you belong to at Illinois State University?", "What is your college Major?", and "What social network do you prefer to use the most?" Knowing the answers to these questions would not be the same for all respondents, a piping command was used to populate each answer into specific sections of the survey, allowing each respondent to take a customized survey. From there, respondents were directed to the beginning of the survey. The survey contained items assessing university and major social identification, intensity of a respondent's social network use, a behavioral index measures, and an intent to donate measure. Respondents were required to be at least 18 years of age and be a current 
student of the university.

\section{Respondents}

A total of $N=272$ respondents were recruited to take part in this research study. However, after careful vetting of the data, 15 respondent were excluded from the analysis because they did not answer the three preliminary piping questions necessary for completing the survey correctly, leaving $N=257$ viable respondents. There were 256 undergraduate $(99.6 \%)$ and 1 graduate $(.4 \%)$ respondents. Overall, the respondents predominantly identified themselves from one of six colleges within Illinois State University, College of Arts and Science 80\% ( $n=206)$, with the remaining respondents representing the College of Applied Science and Technology 7\% ( $n=17)$, College of Business $6 \%(n=15)$, College of Education 4\% ( $n=10)$, College of Nursing 2\% $(n=5)$, and College of Fine Arts 1\% ( $n=4)$. The sample was comprised of $26 \%$ male $(n=68)$ and $74 \%$ female $(n=189)$ with and average age of 20.7 years old.

\section{Measures}

The survey instrument included measures of social identification at both the university and major levels, the intensity of respondents' social network use, a social network communication index, and an intent to donate scale. See Appendix B for full items. To measure the independent variable of university and major social identification, Wang, Walther, and Hancock's (2009) social identification scale was administered twice. The first instance was to assess an individual's level of social identification with the university ( $\propto=.87)$. Items included: “I do not feel a part of Illinois State University’s social group", and "I wouldn't care what happened to Illinois State University". The 
second instance was to assess the same individual's level major identification ( $\propto=.87)$. Items included: “I can see myself as a member of my Major’s social group”, and "My major's social group is important to me."

Three control variables were measured and tested in conjunction with the Social Identification Scale: organizational prestige, organizational attraction, and esteem needs. These variables were controlled for because research shows they may affect a student's social identification. For example, if a student went to Harvard the prestige, attractiveness, and esteem that the university provides may be greater than that of the major. This could eventually skew the data in favor of the university. Organizational prestige was operationalized with Mael and Ashforth's (1992) organizational prestige scale and adjusted to use both university $(\propto=.80)$ and major $(\propto=.80)$ prestige. Items on this scale were used to measure an individual's perception of the university's and major's prestige. Items included: "People in my community think highly of Illinois State University", "Illinois State University is considered one of the best universities", "People from other majors look down at my major", and "A person seeking to advance his career should downplay his association with my major."

Organizational and workgroup attractiveness were assessed with Highhouse, Lievens, and Sinar's (2003) organizational attraction scale. The scale was modified to measure the level of attraction each respondent had towards the university $(\propto=.80)$ and major $(\propto=.86)$. Items included: "For me, ISU would be a good place to attend", "ISU is attractive to me as a place for academia", "I would not be interested in my major except as a last resort", and "A degree from my major is very appealing to me." 
Finally, esteem needs were measured with Pierce, Gardner, Cummings and Durham's (1989) organizational esteem scale. Items were adjusted to apply to university $(\propto=.96)$ and major $(\propto=.97)$ contexts. Items included: "I count at ISU", "I am taken seriously at ISU", "I can make a difference in my major", and "There is faith in me in my major."

To assess the intensity of a respondent's social network use, a modified version of Lampe, Ellison, \& Steinfield's (2007) Facebook intensity scale was used ( $\propto=.87)$. One of the three preliminary survey questions was used to alter the scale by allowing respondents to type in their most-used social network site into an open-ended field in the web survey. A total of nine social network sites were entered, (Facebook, Twitter, Instagram, LinkedIn, Google+, Pintrest, Reddit, Snapchat, and YouTube). The measures in the scale go beyond simple frequency and duration of social network usage by incorporating an emotional aspect to the use of the self-selected social network site. Items from the scale included: [Social network site] is part of my everyday activity, [Social network site] has become part of my daily routine, I feel I am part of the [Social network site] community, I feel out of touch when I haven't logged onto [Social network site] for a while.

To measure respondents' social network communication behaviors towards Illinois State University, an adaptation of Vitak et al. (2011) Political Activity on Facebook index was used. The index was modified to specifically relate to social network site behaviors that were university directed $(\mathrm{KR} 20=.72)$. The index asked respondents to reflect on the stem prompt "In the past 12 months have you..." and included leafs: 
"added or deleted University information from my personal social network site", "became a "fan" of a ISU related page, discussed Illinois State University via a social network site", "posted an update that mentions Illinois State", "joined or left a group about Illinois State University", and "donated money to Illinois State University."

Finally, to measure the dependent variable of intent to donate, Ford and Merchant's (2010) intent to donate scale was adapted $(\propto=.94)$. Items on this scale were modified for use with both university identification and major identification. Items included: "I am likely to donate to [College Major] at ISU after I graduate", "It is unlikely I will give to money to Illinois State University." Four additional hypothetical scenarios, taken from Kramër et al (2014), were used to supplement the intent to donate scale. In these scenarios respondents' were asked if they had a $\$ 100$, how much they would give to Illinois State University or their major and what is the largest amount of money that they would contribute to ISU and/or their major annually. 


\section{CHAPTER IV}

\section{ANALYSIS OF THE DATA}

\section{Statistical Analysis}

A regression analysis was performed to test hypothesis 1 , which expects interaction with the university via social network sites predicts a) university social identification and b) major social identification. To test H1a, a regression was conducted using the independent variable, social network communication behaviors, to predict the dependent variable, university social identification. Regression results revealed social media interaction significantly predicted university social identification, $F(1,248)=$ 21.42, $p<.001, R^{2}=.08$, supporting H1a. To test H1b, a similar regression was conducted using social network communication behaviors with the university as the independent variable and major social identification as the dependent variable. The regression for $\mathrm{H} 1 \mathrm{~b}$ was statistically significant, revealing major social identification could be predicted based on social network communication behaviors, $F(1,248)=10.41$, $\mathrm{p}<.001, R^{2}=.04$. Given that the independent and dependent variables were operationalized as interval-level variables, and the hypothesis predicted a linear relationship between the two, a linear regression was the appropriate to test for $\mathrm{H} 1$. Hypothesis 2 predicts a respondent's major social identification would be stronger than his/her university social identification. However, previous research (Stevenson \& Yerger, 2013; Holmes, 2009; Albert, Ashforth, \& Dutton, 2000) showed that 
organizational prestige, attraction, and esteem may play important roles in the development of social identification, so they were made control variables when testing hypothesis 2 . Since a comparison of two means from the same sample was needed, a paired sample $t$-test was used and revealed respondents' major social identification $(M=$ $5.38, S D=1.08$ ) was not significantly different from their university social identification $(M=5.29, S D=1.08), t(257)=-1.43, p=.16,2$-tailed, even after controlling for organizational prestige, attraction, and esteem. Thus, H2 was not supported.

Hypothesis 3 predicts a) university social identification influences respondents' intent to donate to their university and b) major social identification influences a respondents' intent to donate to their college major. Since the intent to donate scale (Ford \& Merchant, 2010) was adapted for both university and major intent to donate, two dependent variables were created for use when testing $\mathrm{H} 3 \mathrm{a}$ and $\mathrm{H} 3 \mathrm{~b}$ : university intent to donate and major intent to donate. $\mathrm{H} 3 \mathrm{a}$ and $\mathrm{H} 3 \mathrm{~b}$ both predict a linear relationship between interval-level variables, making a linear regression the best choice for both analyses.

To test $\mathrm{H} 3 \mathrm{a}$, a regression was conducted using the independent variable university social identification to predict a student's intent to donate to the university. The results of the regression analysis showed university social identification is a significant predictor of respondents' intent to donate to the university, $F(1,256)=57.18, p<.001, R^{2}=.18$. This shows that students who identified with their university had a greater intent to donate, supporting $\mathrm{H} 3 \mathrm{a}$. The regression performed for $\mathrm{H} 3 \mathrm{~b}$ used the independent variable of major social identification and the dependent variable intent to donate to the major. The 
regression analysis revealed that major social identification is a significant predictor of respondents' intent to donate to their college major, $F(1,256)=22.55, p<.001, R^{2}=.08$, supporting H3b. Though the results of hypothesis 3 may seem straightforward, knowing university and major identification are significant predictors of a respondent's intent to donate creates the foundation for testing whether university or major social identification was a stronger predictor of intent to donate.

The fourth hypothesis predicts that major social identification is a stronger predictor of intent to donate than university social identification. To test this hypothesis, a linear regression was used, with university social identification and major social identification both treated as independent predictor variables, and intent to donate as the dependent variable. The regression was significant $F(2,255),=29.04, p<.001, R^{2}=$ .19. However, counter to the hypothesis, university social identification was a stronger predictor of donation intention $\left(\mathrm{b}^{*}=.40, p<.001\right)$ than major social identification $\left(\mathrm{b}^{*}=\right.$ $.05, p=.19)$. Thus, H4 was not supported. 


\section{CHAPTER V \\ SUMMARY, CONCLUSIONS, AND RECOMMENDATIONS Summary of the Research and Findings}

\section{General Discussion}

The questionable future of federal and state funding for universities, such as the potential loss of the Illinois MAP Grant and the Federal Perkins Loan (Baker, 2016; Bott, 2016), has contributed to the growing need for universities to seek out additional sources of income. To compensate for these potential losses, universities have begun to "lean on alumni networks and foundation money" (Stevens, 2016) to remain financially viable. However, the alumni population becomes geographically dispersed upon graduation, causing their university social identity to be less salient and making engagement behaviors (i.e. volunteering and donation) harder to elicit (Brenner, Serpe, Stryker, 2014; Mael \& Ashforth, 1992). While traditional means of outreach, such as phone calls and emails, remain viable options for attempting to reengage alumni, they lack some of the affordances granted by social network sites to help enhance alumni engagement. According to Farrow and Yuan (2011), social network sites allow for more frequent communication and the development of emotional closeness. Additionally, phone numbers and emails are more likely to change during an individual's life as compared to their social network profile page (Ellison et al., 2007) making social network sites an easy way to reconnect with alumni who may have outdated information. 
This study applied social identity theory to students' social media interactions with their university and major, finding that while both significantly predicted intent to donate, university identification was a stronger predictor of intent to donate. This finding is contrary to previous research (Mael and Ashforth, 1992; Riketta \& Van Dick, 2005; van Knippenberg \& Sleebos, 2006) that found individuals have stronger identification with workgroups as compared to organizational identification. While students have various superordinate identities, each identity has multiple subordinate identities nested within it (Carr, Varney, Blesse, in press). Since subordinate identities cannot exist without the establishment of a superordinate identity, it is understandable why students identify with their university more than their major. This is a significant finding to note because knowing that students' university social identification is stronger than their major identification will change the way universities interact with students.

The analysis of hypothesis 1 shows students who interact with Illinois State University via social network sites reported greater levels of both university and major social identification. Further, the analysis of hypothesis 3 indicated university and major social identification are both significant predictors of intent to donate. So, by increasing students' social network site interaction with Illinois State University, it is possible to increase their intent to donate which creates a greater likelihood for students to give money to help supplement the financial loss facing many universities.

\section{Implications for Theory}

The analysis of social network site use on social identification and behavioral outcomes yielded some interesting results. It was found that when students interacted 
with the university via a social network site, their social identification with both their university and major increased. However, one of the most substantive findings was that although both university and major social identification increased with social network use, university identification was a stronger predictor of intent to donate. This goes against previous findings that workgroups are more salient when compared to the organization and are more important for socialization (Riketta \& Van Dick, 2004; van Knippenberg \& van Schie, 2000).

This deviation from previous research could be explained by the two components of social identity theory: categorization and self-enhancement. Students may choose to enroll at a specific university based on their perceived fit and accessibility with the university and its values; thus categorizing themselves as a member of the university's social group. Additionally, students further categorize themselves into a major based on their personal interests and specializations. Self-enhancement builds off of the categorization process and allows students to satisfy their esteem needs and create a social identification with their university and major. The better satisfied the esteem needs are, the stronger their social identification will be (Vignoles et al., 2006). Students may have identified more with their university because they felt it satisfied their esteem needs better than their major. For example, research on organization identification states that an attractive image and prestigious reputation are used to create and enhance social identification (Gioia, Schultz, \& Corley, 2000; Mael \& Ashforth, 1992). Universities are better equipped to showcase their attraction and prestige because of the amenities they can provide (i.e new facilities, class sizes, or employment outcomes) while majors 
programs may find it more challenging to distinguish themselves from other programs of the same major.

Since the salience of individuals' numerous social identifications shifts, latent identifications need triggers to be (re)activated (Forehand, Deshpandé \& Reed II, 2002). Social network sites act as a catalyst for potentially reactivating university and major social identifications by providing users with opportunities to engage with and absorb information related to the university. The inclusion of social network sites in this study reflects the fact that they are one of the fastest-growing and most popular internet-based technology (Roblyer, 2010) and "almost $60 \%$ of students use social networking to talk about [their] education" (Karlin, 2007, p. 7). However, one aspect of identification that social identity theory neglects to consider is an individual's willingness to reactivate a latent social identity. It may not matter if alumni are given reactivation triggers, such as social network posts and pictures, if they are not willing to internalize their latent social identification.

\section{Implications for Practice}

Knowing social network interaction increases students' intent to donate. Alumni offices should adjust the way they manage their social network site use. Many universities have a social network presence, but do not allocate the appropriate resources to use it effectively (Roblyer et. al, 2010). Posts from alumni offices should be geared towards engaging alumni in a dialogic communication. Rybalko and Seltzer (2010) discuss dialogic communication as ways to engage users on social network sites managed by a company that encourage repeat visits and provide useful information. Any pictures, 
comments or posts should be opportunities for alumni to engage in dialogic communication by responding directly to either the university or other alumni. Each of these interactions will be an opportunity to reactivate latent social identities within alumni to generate donations. While the interactions may not explicitly encourage or seek donations, they can increase alumni social identification which can subsequently increase individuals' intent to donate. However, the use of social network sites to increase social identification should not be reserved exclusively for alumni. As seen in this study, current students are also influenced by social network interactions.

If having high levels of university social identification predicts students' intent to donate, then universities should start building the foundation for university social identification while students are currently enrolled. This can be done by engaging students via social networks sites and providing them opportunities to grow closer to the university. Students who manage to establish a strong level of identification with the university will be more likely to advocate for it. Additionally, these students may require less effort to reengage when they become alumni. To extend this even further, admission offices should consider engaging potential students over social network sites while recruiting for future freshmen classes. If prospective students begin to interact with the university the will begin to develop a social identification towards it. This identification should cause students to feel a closer relationship to the university and thus act in ways that conform to the groups norms (i.e. apply, visit campus, etc.). Starting to build social identification before students even enrolled could make the difference between having engaged and active alumni after graduation and not. There is an opportunity here for 
entities within a university (e.g. admission, marketing, alumni office) to creates some strategic partnerships in order to truly maximize the effects of social network site use on social identification. Some universities have even gone as far as creating dedicated social network monitoring centers that are used to collect and analyze social network data. The analyzed data is then distributed to the appropriate entity to help inform their decisions.

Since the purpose of this study revolved around intent to donate, these findings are not exclusive to the world of academia. Charitable organizations could use social identification and social network interaction strategies to help increase donation and fundraising dollars. It was found that individuals identify stronger with superordinate groups as compared to subordinate groups. Applying this finding to a charitable organization such as the Humane Society help increase donation dollars. If they are looking for financial donations, it would be in their best interest to get potential donors to identify with the Humane Society as an organization rather than specific special interest groups within the organization such as "Stop Puppy Mills" and "Wildlife Protection". It's not that these special interest groups are less important than the overall organization, but they are basically workgroups, which were found to be less effective at eliciting donations as compared to organizational identification

\section{Limitations and Future Research}

One of perhaps the most substantive limitations of this study concerned the respondents' capacity for selective self-inclusion. Those who participated in the study were probably compelled to do so, to some degree, by their university social identification. Social identity theory states individuals will act positively towards, and in 
congruence with, a social identity (i.e. Illinois State University) (Tajfel \& Turner, 1978). This could have lead respondents with high university identification to respond, while potential respondents with low social identification refrained from responding. While there is a chance that selective self-inclusion may have resulted in a Type I error, both the university and major related hypotheses were analyzed to compare within-subject differences, minimizing the effect of selection bias and likely providing a valid comparison for university and major behaviors.

Building off the respondent limitation, there was also a minor change in the population used for the study. Initially, this study sought to use an alumni sample, but due to issues beyond the researcher's control, an undergraduate and graduate population were sampled instead. Using this new sample of current students reduced the ability to generalize these claims to alumni because current students are constantly entrenched in activities that activate university and/or major identification. Alumni, however, lack the constant stimulus to (re)activate their social identifications. This is why social network sites were used as the medium for communication. The results are still useful, because even though current students are not alumni, they will eventually become alumni. It is also possible that since underclassmen responded to the survey, they may not be far enough along in their academic career to develop major social identification, leading to the potential for Type I error.

While this study provides ample data to support the claim that there is a relationship between social network interaction and increased social identification, the method of this study, a cross-sectional survey, cannot establish causality between the 
two. Respondents' social network interactions and initial levels university/major social identification were not measured in a fashion that allowed for a causal claim to be established. It is possible that individuals who have previously established high levels of university and/or major social identification may already be more likely to interact with the university via social network sites. Additionally, the respondents with initially high levels of social identification may already be more inclined to donate regardless of their social network interaction with the university or major.

Lastly, there was an oversight with the social network communication behavior index. While the index was set-up to measure communication behaviors towards the university, the index was not modified to measure the same behaviors towards the major. By not having an index for major behaviors, any analyses concerning social network interaction with the major may have been skewed towards university identification. This oversight may have been an indication of why hypotheses 2 and 4 were not supported.

Future research on the alumni engagement and donation should explore the following items. First, researchers should examine what specific social network interactions increase university and major social identification within alumni. There are a multitude of social network sites, each offering a variety of ways to interact. It would be interesting to see if interaction options such as comments, pictures, news stories, etc. would be more effective at activating social identification than others. Additionally, there are many social network site users who are passive, meaning they use sites to gather information, but rarely contribute information. While these users do not interact in the traditional fashion, it would be interesting to see if passive consumption of social network 
posts for the university or major increases social identification. Building off previous social identification research, future researchers should examine the impact a students' extracurricular involvement on their university and major social identification. Research has shown students who are involved in campus organizations have greater levels of social identification with their university (Gaier, 2005). However, the types and number of extracurricular activities are still up for interpretation. Some have found holding a leadership role in extracurricular activities correlated with increased charitable giving (Clotfelter, 2001) and have linked participation with athletics, student government, and Greek life to charitable giving (Dugan et al., 2000; Monks, 2003). However, Coltfelter (2003) had a contradictory finding when both participation in athletics and extracurricular involvement were not statistically significant predictors of university social identification or charitable giving. The vast majority of alumni and student social identification research has focused solely on university identification, but since major social identification is essentially a workgroup and subordinate identification, (Ashfoth, 2001; Riketta \& Van Dick, 2004; van Knippenberg \& van Schie, 2000) research should aim to study the impact of major social identification.

Last, there needs to be more work on whether intent to donate actually translates into tangible donation dollars. The activation of latent social identities can reignite alumnus' intent to donate, but if they fail to act on that intention, then the reactivation may have been for naught. Future studies may want to include chronemics as a variable when measuring intent to donate. After reactivating university or major social identification, there may be a limited timeframe where universities can take advantage of 
their moment of identity salience and get alumni to donate. This would allow universities to better plan their communication timelines.

\section{Conclusion}

Defining oneself in terms of a relationship with a university or major is not a new concept. However, the inclusion of social network interaction changes how these social identifications are activated. By interacting with a university via a social network site, the salience of both university and major social identification are enhanced. With a stronger more salient identification, students have a higher intent to donate back to the university and their major. As universities become increasingly reliant on alumni gifts to maintain operations (Weerts, Cabrera, \& Sanford, 2009), it is clear they should apply the same social network principals to their alumni outreach in order to increase alumni donations. University interaction with alumni via social network sites should increase intent to donate among alumni; however, universities need to place a considerable amount of effort into maintaining and building relationships with their alumni on these sites. The interactivity and communication affordances social network sites offer (i.e. interaction, synchronous communication, and message reach) make it a superior tool for engaging and interacting with alumni when compared to traditional means of outreach (Farrow \& Yuan, 2011). With an effective social network strategy, universities can increase alumni social identification and generate more financial gifts, making university less reliant on federal funding 


\section{REFERENCES}

Ahmadi, H., Osmani, M., Ibrahim, O., \& Nilashi, M. (2012). Customer relationship management model for UTM Alumni Liaison Unit. History, 2(5). doi: $10.4324 / 9780080949611$

Albert, S., Ashforth, B. E., \& Dutton, J. E. (2000). Organizational identity and identification: Charting new waters and building new bridges. Academy of Management Review, 25, 13-17. doi:10.5465/AMR.2000.2791600

Amiot, C. E., \& Aubin, R. M. (2013). Why and how are you attached to your social group? Investigating different forms of social identification. British Journal of Social Psychology, 52, 563-586. doi:10.1111/bjso.12004

Archibald, R. B., \& Feldman, D. H. (2006). State higher education spending and the tax revolt. Journal of Higher Education, 4, 618. doi:10.1353/jhe.2006.0029.

Ashforth, B. E., \& Mael, F. (1989). Social identity theory and the organization. Academy of Management Review, 14, 20-39. doi:10.5465/AMR.1989.4278999

Ashforth, B. E., (2001). Role transitions in organizational life: An identity-based perspective. Mahwah, N.J.: Lawrence Erlbaum Associates. doi: 10.5465/AMR.2001.5393915

Ashforth, B. E., Harrison, S. H., \& Corley, K. G. (2008). Identification in organizations: An examination of four fundamental questions. Journal of Management, 34, 325 374. doi: 10.1177/0149206308316059

Baker, S. (2016, March 5). Budget impasse forcing some students to question future. Chicago Tribune. Retrieved from: http://www.chicagotribune.com/suburbs/naperville-sun/news/ct-nvs-map-grantimpact-students-st-0304-20160305-story.html

Blanz, M. (1999). Accessibility and fit as determinants of the salience of social categorizations. European Journal of Social Psychology, 29, 43-74. doi: 10.1002/(SICI)1099-0992(199902)29:1<43::AID-EJSP913>3.0.CO;2-Z

Bott, C. (2016, February 19). Rauner vetoes bill to free up \$721M in college funding, including scholarships. Chicago Tribune. Retrieved from: http://www.chicagotribune.com/news/ct-bruce-rauner-vetoes-college-fundingmet-0221-20160219-story.html 
boyd, d. m. \& Ellison, N. B. (2007). Social network sites: Definition, history and scholarship. Journal of Computer-Mediated Communication, 13, 210-230. doi: 10.1109/EMR.2010.5559139

Brenner, P. S., Serpe, R. T., \& Stryker, S. (2014). The causal ordering of prominence and salience in identity theory: An empirical examination. Social Psychology Quarterly, 77(3), 231-252. doi: 10.1177/0190272513518337

Brewer, M. B. (1979). In-group bias in the minimal intergroup situation: A cognitivemotivational analysis. Psychological Bulletin, 86, 307-324. doi: 10.1037/00332909.86.2.307

Bruner, J. S. (1957). Perceptual readiness. Psychological Review 64, 123-152. doi:10.1037/h0043805.

Carr, C. T., Varney, E. J., \& Blesse, J. R. (in press). Social media and intergroup communication: Collapsing and expanding group contexts. In H. Giles \& A. Maass (Eds.),Advances in and prospects for intergroup communication. New York, NY: Peter Lang.

Clotfelter, C. (2003). Alumni giving to elite private colleges and universities. Economics of Education Review, 22, 109-120. doi:10.1016/S0272-7757(02)00028-6

Clotfelter, C. T. (2001). Who are the alumni donors? Giving by two generations of alumni from selective colleges. Nonprofit Management \& Leadership, 12, 119138. http://dx.doi.org/10.1002/nml.12201

Cooper, D., \& Thatcher, S. B. (2010). Identification in organizations: The role of selfconcept orientations and identification motives. Academy of Management Review, 35, 516. doi:10.5465/AMR.2010.53502693

Decoster, S., Camps, J., Stouten, J., Vandevyvere, L., \& Tripp, T. M. (2013). Standing by your organization: The impact of organizational identification and abusive supervision on followers' perceived cohesion and tendency to gossip. Journal of Business Ethics, 118, 623-634. doi:10.1007/s10551-012-1612-z

DeMarie, D., \& Aloise-Young, P. A. (2003). College students' interest in their major. College Student Journal, 37(3), 462.

Dugan, K., Mullin, C. H., \& Siegfried, J. J. (2000). Undergraduate financial aid and subsequent alumni giving behavior. Williams Project on the Economics of Higher Education Discussion Papers. DP-57. doi: 10.1016/j.qref.2003.08.005

Dutton, J. E., Dukerich, J. M., \& Harquail, C. V. (1994). Organizational Images and Member Identification. Administrative Science Quarterly, 39, 239-263. doi: $10.2307 / 2393235$ 
Edwards, M. R. (2005). Organizational identification: A conceptual and operational review. International Journal of Management Reviews, 7, 207-230. doi: 10.1111/j.1468-2370.2005.00114.x

Ellison, N. B., Steinfield, C., \& Lampe, C. (2007). The benefits of Facebook "friends:" Social capital and college students use of online social network sites. Journal of Computer-Mediated Communication, 12, 1143-1168. doi: 10.1111/j.10836101.2007.00367.x

Epitropaki, O. (2013). A multi-level investigation of psychological contract breach and organizational identification through the lens of perceived organizational membership: Testing a moderated-mediated model. Journal of Organizational Behavior, 34, 65-86. doi:10.1002/job.1793

Farrow, H., \& Yuan, Y. C. (2011). Building stronger ties with alumni through Facebook to increase volunteerism and charitable giving. Journal of Computer-Mediated Communication, 16(3), 445-464. doi: 10.1111/j.1083-6101.2011.01550.x

Fisher, R.J., \& Wakefield, K. (1998). Factors leading to group identification: A field study of winners and losers. Psychology \& Marketing, 15, 23-40. doi: 10.1002/(sici)1520-6793(199801)15:1<23::aid-mar3>3.0.co;2-p

Ford, J. B., \& Merchant, A. (2010). Nostalgia drives donations. Journal of Advertising Research, 50(4), 450-459. doi: 10.2501/S0021849910091592

Forehand, M. R., Deshpandé, R., \& Reed II, A. (2002). Identity salience and the influence of differential activation of the social self-schema on advertising response. Journal of Applied Psychology, 87(6), 1086. doi: 10.2139/ssrn.345280

Gaier, S. (2005). Alumni satisfaction with their undergraduate academic experience and the impact on alumni giving and participation. International Journal of Educational Advancement, 5, 279-288. doi: 10.1057/palgrave.ijea.2140220

Gioia, D. A., Schultz, M., \& Corley, K. G. (2000). Organizational identity, image, and adaptive instability. Academy Of Management Review, 25, 63-81. doi:10.5465/AMR.2000.2791603

Giving USA Foundation. (2010). Giving USA 2010: The Annual Report on Philanthropy for the Year 2009. Retrieved from http://www.givingusa.org

Highhouse, S., F. Lievens and E. F. Sinar (2003), Measuring attraction to organizations. Educational and Psychological Measurement, 63, 986-989.doi: $10.1177 / 0013164403258403$

Holmes, J. (2009). Prestige, charitable deductions and other determinants of alumni giving: Evidence from a highly selective liberal arts college. Economics of Education Review, 28(1), 18-28. doi: 10.1016/j.econedurev.2007.10.008 
Hogg, M. A., \& Reid, S. A. (2006). Social identity, self-categorization, and the communication of group norms. Communication Theory, 16, 7-30. doi:10.1111/j.1468-2885.2006.00003.x

Hogg, M. A., \& Terry, D. J. (2000). Social identity and self-categorization processes in organizational contexts. Academy of Management Review, 25, 121-140. doi:10.5465/AMR.2000.2791606

Jacoby-Senghor, D. S., Sinclair, S., \& Smith, C. T. (2015). When bias binds: Effect of implicit outgroup bias on ingroup affiliation. Journal of Personality and Social Psychology, 109(3), 415-433. doi:10.1037/a0039513

Karlin, S. (2007). Examining how youths interact online. School Board News, 73(4), 6-9.

Kim, T., Chang, K., \& Jae Ko, Y. (2010). Determinants of organizational identification and supportive intentions. Journal of Marketing Management, 26, 413-427. doi:10.1080/02672570903485022

Kowalik, E. (2011). Engaging alumni and prospective students through social media. Cutting-edge technologies in higher education, 2, 211-227. doi: 10.1108/s2044-9968(2011)0000002014

Krämer, N. C., Rösner, L., Eimler, S. C., Winter, S., \& Neubaum, G. (2014). Let the weakest link go! Empirical explorations on the relative importance of weak and strong ties on social networking sites. Societies, 4, 785-809. doi: $10.3390 /$ soc4040785

Lertputtarak, S., \& Supitchayangkool, S. (2013). Factors influencing alumni donations. International Journal of Business and Management, 9(3), 170-178. doi: 10.5539/ijbm.v9n3p170

Mael, F. A., \& B. E. Ashforth. (1992) Alumni and their alma mater: A partial test of the reformulated model of organizational identification. Journal of Organizational Behavior, 13, 103-123. doi: 10.1002/job.4030130202

McDearmon, J. (2013). Hail to thee, our Alma Mater: Alumni role identity and the relationship to institutional support behaviors. Research in Higher Education, 54, 283-302. doi: 10.1007/s11162-012-9271-6

Merchant, A., Ford, J. B., \& Sargeant, A. (2010). Charitable organizations' storytelling influence on donors' emotions and intentions. Journal of Business Research, 63(7), 754-762. doi: 10.1016/j.jbusres.2009.05.013

Monks, J. (2003). Patterns of giving to one's alma mater among young graduates from selective institutions. Economics of Education Review, 22, 121-136. doi:10.1016/S0272-7757(02)00036-5 
Mueller, C. W., \& Lawler, E. J. (1999). Commitment to nested organizational units: Some basic principles and preliminary findings. Social Psychology Quarterly, 62, 325-346. doi: 10.2307/2695832

Newman, M. D. and Petrosko, J. M. (2011) Predictors of alumni association membership. Research in Higher Education, 52, 738-759. doi: 10.1007/s11162-011-9213-8

Oakes, P.J. (1987) The salience of social categories. In J.C. Turner, M.A. Hogg, P.J. Oakes, S.D. Reicher, \& M.S. Wetherell (Eds.). The social psychology of stereotyping and group life (pp. 119-143). Oxford, UK: Blackwell.

Okunade, A. A., \& Berl, R. L. (1997). Determinants of charitable giving of business school alumni. Research in Higher Education, 2, 201-215. doi:10.1016/j.econedurev.2007.10.008

Olkkonen, M., \& Lipponen, J. (2006). Prominent consequences of role stress: A metaanalytic review. International Journal of Stress Management, 13, 399-422. doi: 10.1037/1072-5245.13.4.399

Pierce, J. L., Gardner, D. G., Cummings, L. L., \& Dunham, R. B. (1989). Organizationbased self-esteem: Construct definition, measurement, and validation. Academy of Management Journal, 32, 622-648. doi:10.2307/256437

Pratt, M. G. (1998). To be or not to be: Central questions in organizational identification. In D. A. Whetten \& P. C. Godfrey (Eds.), Identity in organizations (pp. 171-207). Thousand Oaks, CA: Sage.

Pratt, M. G., \& Rafaeli, A. (2001). Symbols as a language of organizational relationships. Research in Organizational Behavior, 23, 93-132. doi:10.1016/S01913085(01)23004-4

Reicher, S. D., Spears, R., \& Postmes, T. (1995). A social identity model of deindividuation phenomena. In W. Strobe \& M. Hewstone (Eds.), European review of social psychology (pp.161-198). Chichester, UK: Wiley

Reicher, S.D., Spears, R., \& Haslam, S. A. (2010). The social identity approach in social psychology. Sage identities handbook, 45-62. doi:10.4135/9781446278819.n2

Riketta, M., \& Dick, R. V. (2005). Foci of attachment in organizations: A meta-analytic comparison of the strength and correlates of workgroup versus organizational identification and commitment. Journal of Vocational Behavior, 6, 490-510. doi:10.1016/j.jvb.2004.06.001

Riketta, M., \& van Dick, R. (2005). Foci of attachment in organizations: A meta-analytic comparison of the strength and correlates of workgroup versus organizational identification and commitment. Journal of Vocational Behavior, 67, 490-510. doi: 10.1016/j.jvb.2004.06.001 
Roblyer, M. D., McDaniel, M., Webb, M., Herman, J., \& Witty, J. V. (2010). Findings on Facebook in higher education: A comparison of college faculty and student uses and perceptions of social networking sites. The Internet and Higher Education, 13(3), 134-140. doi: 10.1016/j.iheduc.2010.03.002

Rybalko, S., \& Seltzer, T. (2010). Dialogic communication in 140 characters or less: How Fortune 500 companies engage stakeholders using Twitter. Public Relations Review, 36(4), 336-341. doi: 10.1016/j.pubrev.2010.08.004

Sassenberg, K., \& Boos, M. (2003) Attitude change in computer mediated communication: Effects of anonymity and category norms. Group Processes and Intergroup Relations, 6, 405-422. doi: 10.1177/13684302030064006

Schreyögg, G., \& Geiger, D. (2007). The significance of distinctiveness: A proposal for rethinking organizational knowledge. Organization Science, 14, 77-89. doi:10.1177/1350508407071861

Scott, C. R. (2007). Communication and social identity theory: Existing and potential connections in organizational identification research. Communication Studies, 58, 123-138. doi:10.1080/10510970701341063

Sluss, D. M., \& Ashforth, B. E. (2008). How relational and organizational identification converge: Processes and conditions. Organization Science, 19, 807-823. doi: 10.1287/orsc. 1070.0349

Stapel, D. A., \& Koomen, W. (2000). Distinctness of others and malleability of selves: Their impact on social comparison effects. Journal of Personality and Social Psychology, 79, 1068-1087. doi: 10.1037/0022-3514.79.6.1068

Stephenson, A. L. (2013). The effect of brand identification on alumni supportive behaviors (Doctoral dissertation, Indiana University of Pennsylvania).

Stephenson, A., \& Yerger, D. (2014). Optimizing engagement: brand identification and alumni donation behaviors. International Journal of Educational Management, 28(6), 765-778. doi: 10.1108/ijem-04-2013-0057

Stets, J. E., \& Burke, P. J. (2000). Identity theory and social identity theory. Social Psychology Quarterly, (3). 224-236. doi: 10.2307/2695870

Stevens, H. (2016, February 29). At Eastern Illinois University, my alma mater, a heartbreaking budget mess. Chicago Tribune. Retrieved from: http://www.chicagotribune.com/lifestyles/stevens/ct-fund-eiu-budget-alumbalancing-0229-20160229-column.html 
Sun, X., Hoffman, S. C., \& Grady, M. L. (2007). A multivariate causal model of alumni giving: Implications for alumni fundraisers. International Journal of Educational Advancement, 7(4), 307-332. doi: 10.1057/palgrave.ijea.2150073

Tajfel, H. (1978). Differentiation between social groups. London, England: Academic Press.

Tajfel, H., \& Turner, J. C. (1979). An integrative theory of inter-group conflict. In W. G. Austin \& S. Worchel (Eds.), The social psychology of intergroup relations (p. 3347). Monterey, CA: Brooks-Cole.

Tajfel, H., \& Turner, J. C. (1986). The social identity theory of intergroup behavior. In S. Worchel \& W. G. Austin (Eds.), The psychology of intergroup relations (pp. 7-24). Chicago, IL: Nelson-Hall.

Tsao, J. C., \& Coll, G. (2005). To give or not to give: factors determining alumni intent to make donations as a PR outcome. Journalism \& Mass Communication Educator, 59(4), 381- 392. http://dx.doi.org/10.1177/107769580405900407

Turner, J. C. (1987). Rediscovering the social group: a self-categorization theory. Oxford, UK: Blackwell.

van Knippenberg, D., \& Sleebos, E. (2006). Organizational identification versus organizational commitment: Self-definition, social exchange, and job attitudes. Journal of Organizational Behavior, 27, 571-584. doi: 10.1037/e518532013-507

van Knippenberg, D., \& van Schie, E.C.M. (2000). Foci and correlates of organizational identification. Journal of Occupational and Organizational Psychology,73, 137147. doi: $10.1348 / 096317900166949$

Vignoles, V. L., Regalia, C., Manzi, C., Golledge, J., \& Scabini, E. (2006). Beyond selfesteem: influence of multiple motives on identity construction. Journal of Personality and Social psychology, 90(2), 308. doi: 10.1037/0022-3514.90.2.308

Vitak, J., Zube, P., Smock, A., Carr, C. T., Ellison, N., \& Lampe, C. (2011). It's Complicated: Facebook users' political participation in the 2008 election. Cyberpsychology, Behavior \& Social Networking, 14, 107-114. doi:10.1089/cyber.2009.0226

Vough, H. (2011). Not all identifications are created equal: Exploring employee accounts for workgroup, organizational, and professional identification. Organization Science, 23, 778-800. doi: 10.1287/orsc.1110.0654

Wang, Z., Walther, J. B., \& Hancock, J. T. (2009). Social identification and interpersonal communication in computer-mediated communication: What you do versus who you are in virtual groups. Human Communication Research, 35, 59-85. doi: 10.1111/j.1468-2958.2008.01338.x 
Weerts, D. J., \& Ronca, J. M. (2008). Characteristics of alumni donors who volunteer at their alma mater. Research in Higher Education, 49(3), 274-292. Retrieved from http://www.jstor.org/stable/25704562

Weerts, D. J., Cabrera, A. F., \& Sanford, T. (2010). Beyond giving: Political advocacy and volunteer behaviors of public university alumni. Research in Higher Education, 51(4), 346-365. doi: 10.1007/s11162-009-9158-3

Wunnava, P. V., \& Lauze, M. A. (2001). Alumni giving at a small liberal arts college: evidence from consistent and occasional donors. Economics of Education Review, 20, 533-543. doi:10.1016/S0272-7757(00)00023-6

Zeng, L., Hall, H., \& Pitts, M. J. (2012). Cultivating a community of learners: The potential challenges of social media in Higher Education. Social media: Usage and impact, 111-126. doi: 10.1007/s11162-009-9158-3

Zhao, S., Grasmuck, S., \& Martin, J. (2008). Identity construction on Facebook: Digital empowerment in anchored relationships. Computers in Human Behavior, 24, 1816-1836. doi:10.1016/j.chb.2008.02.012 


\section{APPENDIX A}

\section{INFORMED CONSENT}

You have been invited to participate in a research study examining students' use of social media and its effect on social identity by Eric Varney, a graduate student completing his thesis at Illinois State University. You have been selected as a possible participant in this study because you are 18 years or older and you are an Illinois State University student. I ask that you read this consent form and ask any questions you may have before agreeing to participate in this study. Your responses will be protected and remain confidential. The following is a brief description of the project and your rights as a research participant.

\section{Purpose of the Study:}

The purpose of this study is to understand how students interaction with Illinois State University (ISU) via social media affects their affinity towards ISU.

\section{Procedures and Duration of the Study:}

Participants in this project will answer a series of short survey questions. The questionnaire will take approximately 15 minutes to complete. The research team will use aggregate data (in summary form only, such as averages and mean scores, with no identifying information) in the research report in order to maintain your anonymity.

\section{Risks and Benefits of being in the Study:}

There is a risk of psychological discomfort answering some questions about your university experiences and relations; but you are free to discontinue the survey at any time should you feel such distress. You will not receive direct benefit from participating; but your responses will help us better-understand university-student relations.

\section{Confidentiality:}

Your participation is voluntary and there is no penalty for not participating. Your responses will remain anonymous and no identifying information is being collected. Your personal information will not be linkable to you personally. The records of this study will be kept private. Data will be reported in an aggregate or summary form only. Voluntary Nature of the Study:

Participation in this study is voluntary. Your decision whether or not to participate will not affect your current or future relations with Illinois State University. If you decide to participate, you are free not to answer questions you do not like or withdraw from the study at any time without consequences. If you feel uncomfortable, you may withdraw from the study at any time without penalty. 


\section{Contacts and Questions:}

The primary investigator for this study is Dr. Caleb Carr. If you have any questions regarding the study, please contact him by email at ctcarr@ilstu.edu. If you have any questions or concerns regarding your rights as a research participant, you are encouraged to contact the Research Ethics and Compliance office at Illinois State University by phone at (309) 438-2520.

\section{Statement of Consent:}

I have read the above information. By clicking the hyperlink below you are consenting to the study. We want to thank you for your participation in this study and let you know that we appreciate your help.

I have voluntarily agreed to participate in this study. I understand that I may withdraw my participation at any time.

Click "Next" To Participate 


\section{APPENDIX B \\ SURVEY INSTRUMENT}

\section{ISU Students and Social Media Habits}

\section{Demographics}

To begin, we would like to get some information about you. Your answers to these questions will help us better understand the opinions you express in other sections of this questionnaire.

1. What academic department do you belong to at Illinois State University?*

2. What is your college Major?* (If you are double majoring, please choose the one you associate with the most.)

3. What social network do you prefer to use the most? (e.g., Facebook, Twitter, Instagram, Google+, LinkedIn)*

\section{Your Perceptions of ISU and Your Major}

The following sets of questions ask about your perception of yourself in relation to Illinois State University as a college and of your undergraduate major.

4. For the next set of items, please indicate the answer that best describes your feelings or response to each statement regarding your connection to Illinois State University.

\begin{tabular}{|c|c|c|c|c|c|c|c|}
\hline & 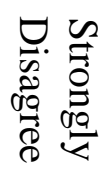 & 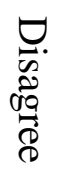 & 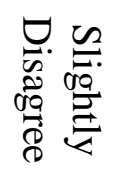 & 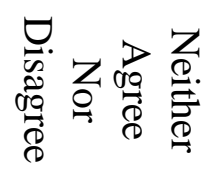 & 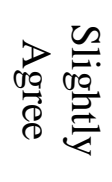 & $\underset{\substack{D \\
\mathbb{D}}}{\stackrel{D}{D}}$ & 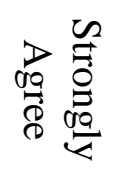 \\
\hline $\begin{array}{l}\text { I wouldn't care } \\
\text { what happened } \\
\text { to Illinois State } \\
\text { University. }\end{array}$ & 1 & 2 & 3 & 4 & 5 & 6 & 7 \\
\hline $\begin{array}{l}\text { I can see } \\
\text { myself as a } \\
\text { member of } \\
\text { Illinois State }\end{array}$ & 1 & 2 & 3 & 4 & 5 & 6 & 7 \\
\hline
\end{tabular}




\begin{tabular}{|l|l|l|l|l|l|l|l|}
\hline $\begin{array}{l}\text { University's } \\
\text { social group. }\end{array}$ & 1 & 2 & 3 & 4 & 5 & 6 & 7 \\
\hline $\begin{array}{l}\text { Illinois State } \\
\text { University's } \\
\text { social group is } \\
\text { important to } \\
\text { me. }\end{array}$ & 1 & 2 & 3 & 4 & 5 & 6 & 7 \\
\hline $\begin{array}{l}\text { I do not feel a } \\
\text { part of Illinois } \\
\text { State }\end{array}$ & 1 & 2 & 3 & 4 & 5 & 6 & 7 \\
$\begin{array}{l}\text { University's } \\
\text { social group. }\end{array}$ & 1 & 2 & 3 & 4 & 5 & 6 & 7 \\
\hline $\begin{array}{l}\text { I feel involved } \\
\text { in Illinois State } \\
\text { University's } \\
\text { social group. }\end{array}$ & 1 & & & & & & \\
\hline $\begin{array}{l}\text { I am pleased to } \\
\text { be a member } \\
\text { of this group. }\end{array}$ & 1 & & & & & & \\
\hline
\end{tabular}

5. For the next set of items, please indicate the answer that best describes your feelings or response to each statement regarding your connection to your major.

\begin{tabular}{|c|c|c|c|c|c|c|c|}
\hline & 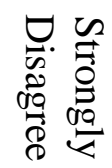 & 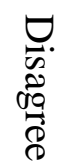 & 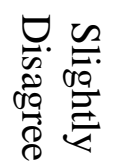 & 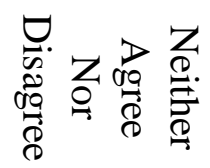 & 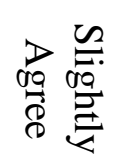 & 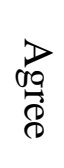 & 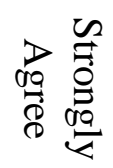 \\
\hline $\begin{array}{l}\text { I am pleased to } \\
\text { be a member } \\
\text { of this group. }\end{array}$ & 1 & 2 & 3 & 4 & 5 & 6 & 7 \\
\hline $\begin{array}{l}\text { The } \\
\text { major's social } \\
\text { group is } \\
\text { important to } \\
\text { me. }\end{array}$ & 1 & 2 & 3 & 4 & 5 & 6 & 7 \\
\hline $\begin{array}{l}\text { I feel involved } \\
\text { in the } \\
\text { major's social } \\
\text { group. }\end{array}$ & 1 & 2 & 3 & 4 & 5 & 6 & 7 \\
\hline $\begin{array}{l}\text { I do not feel } \\
\text { like a part of } \\
\text { the major's } \\
\text { social group. }\end{array}$ & 1 & 2 & 3 & 4 & 5 & 6 & 7 \\
\hline
\end{tabular}




\begin{tabular}{|l|l|l|l|l|l|l|l|}
\hline $\begin{array}{l}\text { I wouldn't care } \\
\text { what happened } \\
\text { to the } \\
\text { major. }\end{array}$ & 1 & 2 & 3 & 4 & 5 & 6 & 7 \\
\hline $\begin{array}{l}\text { I can see } \\
\text { myself as a } \\
\text { member of the } \\
\text { major's }\end{array}$ & 1 & 2 & 3 & 4 & 5 & 6 & 7 \\
\hline $\begin{array}{l}\text { social group. }\end{array}$ & & & & & & \\
\hline
\end{tabular}

\section{Social Media Use and Attitudes}

6. For the next set of items, please indicate the answer that best describes your feelings or response to the statements regarding your use of the indicated social medium.

\begin{tabular}{|c|c|c|c|c|c|c|c|}
\hline & 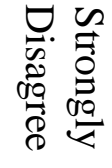 & 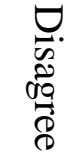 & 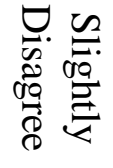 & 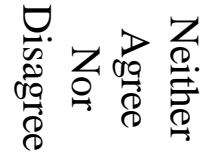 & 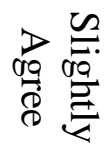 & 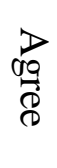 & 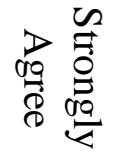 \\
\hline $\begin{array}{l}\text { is part of } \\
\text { my everyday } \\
\text { activity. }\end{array}$ & 1 & 2 & 3 & 4 & 5 & 6 & 7 \\
\hline $\begin{array}{l}\text { I am proud to } \\
\text { tell people I'm } \\
\text { on } \_ \text {. }\end{array}$ & 1 & 2 & 3 & 4 & 5 & 6 & 7 \\
\hline $\begin{array}{l}\text { become part of } \\
\text { my daily } \\
\text { routine. }\end{array}$ & 1 & 2 & 3 & 4 & 5 & 6 & 7 \\
\hline $\begin{array}{l}\text { I feel out of } \\
\text { touch when I } \\
\text { haven't logged } \\
\text { onto__ for a } \\
\text { while. }\end{array}$ & 1 & 2 & 3 & 4 & 5 & 6 & 7 \\
\hline $\begin{array}{l}\text { I feel I am part } \\
\text { of the } \\
\text { community. }\end{array}$ & 1 & 2 & 3 & 4 & 5 & 6 & 7 \\
\hline $\begin{array}{l}\text { I would be } \\
\text { sorry if _ shut } \\
\text { down. }\end{array}$ & 1 & 2 & 3 & 4 & 5 & 6 & 7 \\
\hline
\end{tabular}


7. Approximately how many TOTAL Friends/Followers do you have? The value must be greater than or equal to 0 .

8. In the past week, on average, approximately how much time PER DAY (in minutes) have you spent actively using

9. Approximately how many of your current Friends/Followers do you know from college?

\section{ISU and Major Attraction}

The following sets of questions ask about your perception of yourself in relation to Illinois State University as a university and of your undergraduate major.

10. For the next set of items, please indicate the answer that best describes your feelings or response to each statement regarding your connection to Illinois State University.

\begin{tabular}{|c|c|c|c|c|c|c|c|}
\hline & 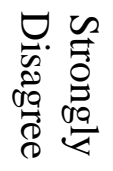 & 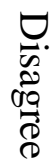 & 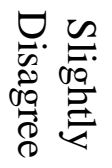 & 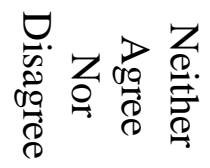 & 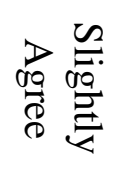 & 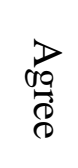 & 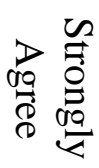 \\
\hline $\begin{array}{l}\text { I was not } \\
\text { interested in } \\
\text { Illinois } \\
\text { State } \\
\text { University } \\
\text { except as a } \\
\text { last resort. }\end{array}$ & 1 & 2 & 3 & 4 & 5 & 6 & 7 \\
\hline $\begin{array}{l}\text { Illinois } \\
\text { State } \\
\text { University } \\
\text { was } \\
\text { attractive to } \\
\text { me as an } \\
\text { academic } \\
\text { institution. }\end{array}$ & 1 & 2 & 3 & 4 & 5 & 6 & 7 \\
\hline $\begin{array}{l}\text { For me, } \\
\text { Illinois } \\
\text { State } \\
\text { University } \\
\text { was a good } \\
\text { institution } \\
\text { to attend. }\end{array}$ & 1 & 2 & 3 & 4 & 5 & 6 & 7 \\
\hline
\end{tabular}




\begin{tabular}{|c|c|c|c|c|c|c|c|}
\hline $\begin{array}{l}\text { A degree } \\
\text { from Illinois } \\
\text { State } \\
\text { University } \\
\text { was very } \\
\text { appealing to } \\
\text { me. }\end{array}$ & 1 & 2 & 3 & 4 & 5 & 6 & 7 \\
\hline $\begin{array}{l}\text { I was } \\
\text { interested in } \\
\text { learning } \\
\text { more about } \\
\text { Illinois } \\
\text { State } \\
\text { University } \\
\text { before } \\
\text { attending. }\end{array}$ & 1 & 2 & 3 & 4 & 5 & 6 & 7 \\
\hline
\end{tabular}

11. For the next set of items, please indicate the answer that best describes your feelings or response to each statement regarding your connection to your major.

\begin{tabular}{|c|c|c|c|c|c|c|c|}
\hline & 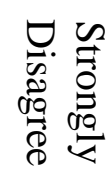 & 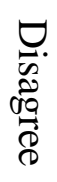 & 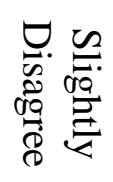 & 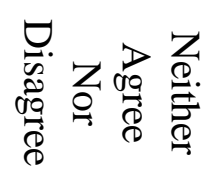 & 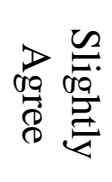 & 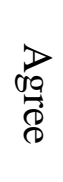 & 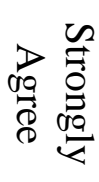 \\
\hline $\begin{array}{l}\text { was an } \\
\text { attractive } \\
\text { major. }\end{array}$ & 1 & 2 & 3 & 4 & 5 & 6 & 7 \\
\hline $\begin{array}{l}\text { I chose the }- \\
\text { major as a last } \\
\text { resort. }\end{array}$ & 1 & 2 & 3 & 4 & 5 & 6 & 7 \\
\hline $\begin{array}{l}\text { I was } \\
\text { interested in } \\
\text { learning more } \\
\text { about the - } \\
\text { major before } \\
\text { attending. }\end{array}$ & 1 & 2 & 3 & 4 & 5 & 6 & 7 \\
\hline $\begin{array}{l}\text { A degree } \\
\text { in was very } \\
\text { appealing to } \\
\text { me. }\end{array}$ & 1 & 2 & 3 & 4 & 5 & 6 & 7 \\
\hline $\begin{array}{l}\text { For me, } \\
\text { was a good } \\
\text { major to } \\
\text { choose. }\end{array}$ & 1 & 2 & 3 & 4 & 5 & 6 & 7 \\
\hline
\end{tabular}




\section{ISU and Major Prestige}

The following sets of questions ask about your perception of Illinois State University's prestige as a college and of your undergraduate major's prestige.

12. For the next set of items, please indicate the answer that best describes your feelings or response to each statement regarding your connection to Illinois State University.

\begin{tabular}{|c|c|c|c|c|c|c|c|}
\hline & 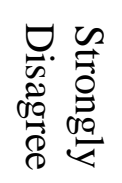 & 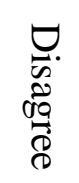 & 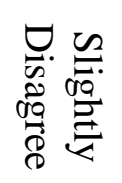 & 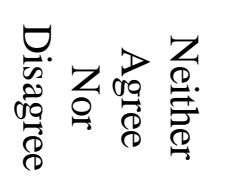 & 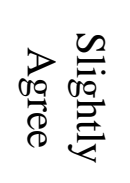 & $\begin{array}{l}\vec{D} \\
0 \\
\vec{d} \\
0\end{array}$ & 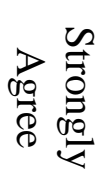 \\
\hline $\begin{array}{l}\text { People from } \\
\text { other } \\
\text { universities } \\
\text { look down at } \\
\text { Illinois State } \\
\text { University. }\end{array}$ & 1 & 2 & 3 & 4 & 5 & 6 & 7 \\
\hline $\begin{array}{l}\text { Being a } \\
\text { graduate of } \\
\text { Illinois State } \\
\text { University is } \\
\text { considered } \\
\text { prestigious. }\end{array}$ & 1 & 2 & 3 & 4 & 5 & 6 & 7 \\
\hline $\begin{array}{l}\text { People think } \\
\text { highly of } \\
\text { Illinois State } \\
\text { University. }\end{array}$ & 1 & 2 & 3 & 4 & 5 & 6 & 7 \\
\hline $\begin{array}{l}\text { Illinois State } \\
\text { University is } \\
\text { considered one } \\
\text { of the best } \\
\text { universities in } \\
\text { the nation. }\end{array}$ & 1 & 2 & 3 & 4 & 5 & 6 & 7 \\
\hline $\begin{array}{l}\text { When } \\
\text { companies are } \\
\text { recruiting new } \\
\text { employees, } \\
\text { they would not } \\
\text { want } \\
\text { employees } \\
\text { with a degree } \\
\text { from Illinois }\end{array}$ & 1 & 2 & 3 & 4 & 5 & 6 & 7 \\
\hline
\end{tabular}




\begin{tabular}{|l|l|l|l|l|l|l|l|}
\hline $\begin{array}{l}\text { State } \\
\text { University. }\end{array}$ & & & & & & \\
\hline $\begin{array}{l}\text { Graduates of } \\
\text { ISU would be } \\
\text { proud to have } \\
\text { their children } \\
\text { attend Illinois } \\
\begin{array}{l}\text { State } \\
\text { University. }\end{array}\end{array}$ & 1 & 2 & 3 & 4 & 5 & 6 & 7 \\
\hline $\begin{array}{l}\text { A person } \\
\text { seeking to } \\
\text { advance his } \\
\text { career should } \\
\text { downplay his } \\
\text { association } \\
\text { with Illinois } \\
\begin{array}{l}\text { State } \\
\text { University. }\end{array}\end{array}$ & 1 & 2 & 3 & 4 & 5 & 6 & 7 \\
\hline $\begin{array}{l}\text { Illinois State } \\
\begin{array}{l}\text { University } \\
\text { does not have a } \\
\text { good } \\
\text { reputation. }\end{array}\end{array}$ & 1 & 2 & 3 & 4 & 5 & 6 & 7 \\
\hline
\end{tabular}

\section{ISU and Major Prestige Continued}

13. For the next set of items, please indicate the answer that best describes your feelings or

\begin{tabular}{|c|c|c|c|c|c|c|c|}
\hline & 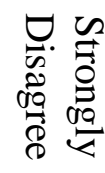 & 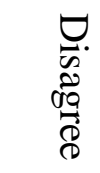 & 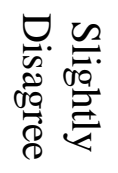 & 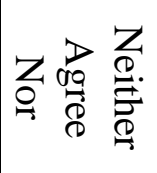 & 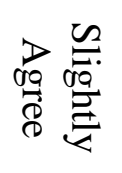 & $\begin{array}{l}\overrightarrow{0} \\
\frac{0}{0} \\
0\end{array}$ & 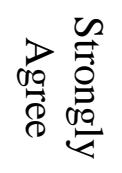 \\
\hline $\begin{array}{l}\text { Graduates of } \\
\text { the major } \\
\text { would be } \\
\text { proud to } \\
\text { have their } \\
\text { children } \\
\text { pursue }\end{array}$ & 1 & 2 & 3 & 4 & 5 & 6 & 7 \\
\hline $\begin{array}{l}\text { People think } \\
\text { highly of } \\
\text { majors. }\end{array}$ & 1 & 2 & 3 & 4 & 5 & 6 & 7 \\
\hline
\end{tabular}




\begin{tabular}{|c|c|c|c|c|c|c|c|}
\hline $\begin{array}{l}\text { The } \\
\text { major does } \\
\text { not have a } \\
\text { good } \\
\text { reputation. }\end{array}$ & 1 & 2 & 3 & 4 & 5 & 6 & 7 \\
\hline $\begin{array}{l}\text { Being a } \\
\text { major is } \\
\text { considered } \\
\text { prestigious. }\end{array}$ & 1 & 2 & 3 & 4 & 5 & 6 & 7 \\
\hline $\begin{array}{l}\text { People from } \\
\text { other majors } \\
\text { look down at } \\
\text { _ majors. }\end{array}$ & 1 & 2 & 3 & 4 & 5 & 6 & 7 \\
\hline $\begin{array}{l}\text { When } \\
\text { companies } \\
\text { are recruiting } \\
\text { new } \\
\text { employees, } \\
\text { they would } \\
\text { not want } \\
\text { employees } \\
\text { with a degree } \\
\text { in }\end{array}$ & 1 & 2 & 3 & 4 & 5 & 6 & 7 \\
\hline $\begin{array}{l}\text { is } \\
\text { considered } \\
\text { one of the } \\
\text { best majors. }\end{array}$ & 1 & 2 & 3 & 4 & 5 & 6 & 7 \\
\hline $\begin{array}{l}\text { A person } \\
\text { seeking to } \\
\text { advance his } \\
\text { career should } \\
\text { downplay his } \\
\text { association } \\
\text { as a major. }\end{array}$ & 1 & 2 & 3 & 4 & 5 & 6 & 7 \\
\hline
\end{tabular}

\section{ISU and Major Esteem}

You're almost done--just two sets of questions left. The following sets of questions ask about your personal connection in relation to Illinois State University and of your undergraduate major. 
14. For the next set of items, please indicate the answer that best describes your feelings or response to each statement regarding your connection to Illinois State University.

\begin{tabular}{|c|c|c|c|c|c|c|c|}
\hline & 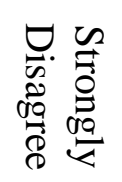 & 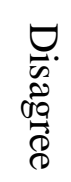 & 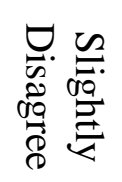 & 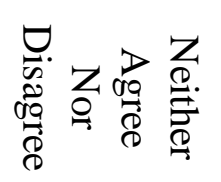 & 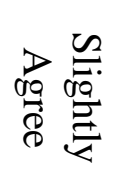 & 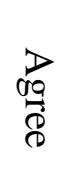 & 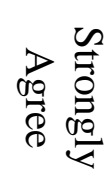 \\
\hline I count at ISU. & 1 & 2 & 3 & 4 & 5 & 6 & 7 \\
\hline $\begin{array}{l}\text { I am important } \\
\text { at ISU. }\end{array}$ & 1 & 2 & 3 & 4 & 5 & 6 & 7 \\
\hline $\begin{array}{l}\text { I am taken } \\
\text { seriously at } \\
\text { ISU. }\end{array}$ & 1 & 2 & 3 & 4 & 5 & 6 & 7 \\
\hline $\begin{array}{l}\text { I am trusted at } \\
\text { ISU. }\end{array}$ & 1 & 2 & 3 & 4 & 5 & 6 & 7 \\
\hline $\begin{array}{l}\text { I can make a } \\
\text { difference at } \\
\text { ISU. }\end{array}$ & 1 & 2 & 3 & 4 & 5 & 6 & 7 \\
\hline $\begin{array}{l}\text { I am valuable } \\
\text { at ISU. }\end{array}$ & 1 & 2 & 3 & 4 & 5 & 6 & 7 \\
\hline $\begin{array}{l}\text { I am helpful at } \\
\text { ISU. }\end{array}$ & 1 & 2 & 3 & 4 & 5 & 6 & 7 \\
\hline $\begin{array}{l}\text { There is faith } \\
\text { in me at ISU. }\end{array}$ & 1 & 2 & 3 & 4 & 5 & 6 & 7 \\
\hline $\begin{array}{l}\text { I am efficient } \\
\text { at ISU. }\end{array}$ & 1 & 2 & 3 & 4 & 5 & 6 & 7 \\
\hline $\begin{array}{l}\text { I am } \\
\text { cooperative at } \\
\text { ISU. }\end{array}$ & 1 & 2 & 3 & 4 & 5 & 6 & 7 \\
\hline
\end{tabular}

\section{ISU and Major Esteem Continued}

15. For the next set of items, please indicate the answer that best describes your feelings or response to each statement regarding your connection to your major.

\begin{tabular}{|c|c|c|c|c|c|c|c|}
\hline & 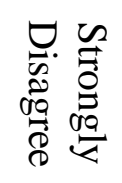 & 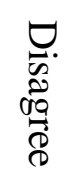 & 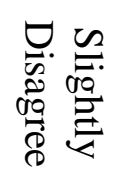 & 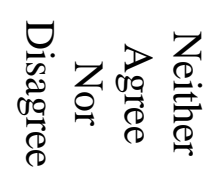 & 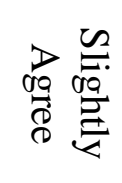 & 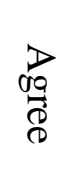 & 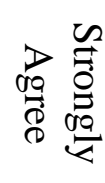 \\
\hline $\begin{array}{l}\text { I am valuable } \\
\text { as a major. }\end{array}$ & 1 & 2 & 3 & 4 & 5 & 6 & 7 \\
\hline
\end{tabular}




\begin{tabular}{|c|c|c|c|c|c|c|c|}
\hline $\begin{array}{l}\text { I am } \\
\text { cooperative in } \\
\text { the major. }\end{array}$ & 1 & 2 & 3 & 4 & 5 & 6 & 7 \\
\hline $\begin{array}{l}\text { I can make a } \\
\text { difference as a } \\
\text { major. }\end{array}$ & 1 & 2 & 3 & 4 & 5 & 6 & 7 \\
\hline $\begin{array}{l}\text { I am efficient } \\
\text { as a major. }\end{array}$ & 1 & 2 & 3 & 4 & 5 & 6 & 7 \\
\hline $\begin{array}{l}\text { There is faith } \\
\text { in me as a } \\
\text { major. }\end{array}$ & 1 & 2 & 3 & 4 & 5 & 6 & 7 \\
\hline $\begin{array}{l}\text { I count as a } \\
\text { major. }\end{array}$ & 1 & 2 & 3 & 4 & 5 & 6 & 7 \\
\hline $\begin{array}{l}\text { I am trusted as } \\
\text { a major. }\end{array}$ & 1 & 2 & 3 & 4 & 5 & 6 & 7 \\
\hline $\begin{array}{l}\text { I am helpful as } \\
\text { a major. }\end{array}$ & 1 & 2 & 3 & 4 & 5 & 6 & 7 \\
\hline $\begin{array}{l}\text { I am taken } \\
\text { seriously as a } \\
\text { major. }\end{array}$ & 1 & 2 & 3 & 4 & 5 & 6 & 7 \\
\hline $\begin{array}{l}\text { I am important } \\
\text { as a major. }\end{array}$ & 1 & 2 & 3 & 4 & 5 & 6 & 7 \\
\hline
\end{tabular}

\section{Interacting with Illinois State University}

In the past 12 months how many times have you...

16. Added or deleted University information from my personal social network site.

17. Became a "fan" of an ISU related page.

18. Discussed Illinois State University via a social network site.

19. Joined or left a group about Illinois State University.

20. Posted an update that mentions Illinois State University.

21. Posted a photo that has something to do with Illinois State University.

22. Posted a photo of someone at Illinois State University.

23. Posted a wall comment about Illinois State University.

24. Posted a link about Illinois State University.

25. Posted a Facebook Note that has something to do with Illinois State University.

26. Learned about an Illinois State University event via social media.

27. Donated money to Illinois State University.

28. Read a social network post related to Illinois State University.

29. Viewed a photo of Illinois State University via a social network site.

30. Attended an ISU sponsored sporting event.

31. Attended a homecoming event. 


\section{Future Donations}

32. This last set of questions...

\begin{tabular}{|c|c|c|c|c|c|c|c|}
\hline & 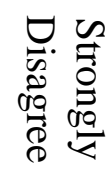 & 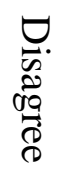 & 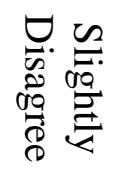 & 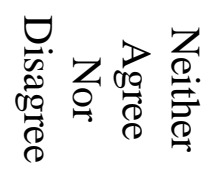 & 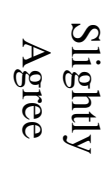 & $\underset{d 0}{D}$ & 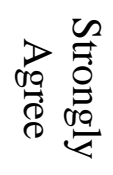 \\
\hline $\begin{array}{l}\text { I am likely to } \\
\text { donate to at } \\
\text { ISU after I } \\
\text { graduate. }\end{array}$ & 1 & 2 & 3 & 4 & 5 & 6 & 7 \\
\hline $\begin{array}{l}\text { It is unlikely I } \\
\text { will give to } \\
\text { money to } \\
\text { Illinois State } \\
\text { University. }\end{array}$ & 1 & 2 & 3 & 4 & 5 & 6 & 7 \\
\hline $\begin{array}{l}\text { I will } \\
\text { definitely } \\
\text { donate to at } \\
\text { ISU in the } \\
\text { future. }\end{array}$ & 1 & 2 & 3 & 4 & 5 & 6 & 7 \\
\hline $\begin{array}{l}\text { It is unlikely I } \\
\text { will give to } \\
\text { money to at } \\
\text { ISU. }\end{array}$ & 1 & 2 & 3 & 4 & 5 & 6 & 7 \\
\hline $\begin{array}{l}\text { I will } \\
\text { definitely } \\
\text { donate to } \\
\text { Illinois State } \\
\text { University in } \\
\text { the future. }\end{array}$ & 1 & 2 & 3 & 4 & 5 & 6 & 7 \\
\hline $\begin{array}{l}\text { I am likely to } \\
\text { donate to } \\
\text { Illinois State } \\
\text { University in } \\
\text { the future }\end{array}$ & 1 & 2 & 3 & 4 & 5 & 6 & 7 \\
\hline
\end{tabular}

33. What is the largest amount of money you would consider pledging annually to Illinois State University upon graduation?

34. What is the largest amount of money you would consider pledging annually to at ISU upon graduation? 
35. Imagine that you had won a contest where you received $\$ 100$ that had to be donated to various nonprofits. You could not keep any of the money for yourself. Of that $\$ 100$, how much would you give to Illinois State University? The value must be between 0 and 100 , inclusive.

36. Imagine that you had won a contest where you received $\$ 100$ that had to be donated to various nonprofits. You could not keep any of the money for yourself. Of that $\$ 100$, how much would you give to MAJOR? The value must be between 0 and 100 , inclusive.

\section{Demographics Continued}

This last set of questions ask a bit more about you and your personal experiences. Again, all responses will be kept confidential and cannot be linked to specific respondents.

37. What is your biological gender?

Male Female

38. What was your age (in years) on your last birthday? The value must be greater than or equal to 18 .

39. What year did you receive your Bachelor's degree from Illinois State University? The value must be less than or equal to 2015 .

40. Approximately how many miles away from Illinois State University do you currently live? The value must be greater than or equal to 0 .

41. Please list up to five extracurricular, co-curricular or sports teams you participated in while you attended Illinois State University.

1)

2)

3)

4)

5) 